講座

\title{
わかりやすい環境影響評価書を作るには（6）
}

島津康男*

目次

1. はじめに

2. よい評価書とは

3.乙れまでの事例の分析

4. 三つの技術指針

5.「わかりやすい」とは

手による気になるか, やさしい文章

か, 読みやすい構成か
6.「正確に伝える」とは

7.「知りたいてとが書いてある」とは

8. 準備書之評価書

9. 概要版

10. 現況調查計画書

11. 公聴会等の運営

12. 情報伝達の技術指針

\section{3. 概要版作成の事例研究}

京滋バイパス宇治地区

(日本道路公団) 山口台土地区画整理（川崎市）

一宮衛生処理場（宮市）

14. おわりに

（本号所載はゴジックの分）

\section{3 一宮市衛生処理場の建設に係る環境影響評価}

1 全体としての特幑

(1) 全体のページ数は妥光であり, 事業㖕画, 地域の 概況の占める比率はそれぞれ5.6\%，13.0\%で，これ も妥当である。

(2) ページ当りの本支は30字 $\times 30$ 行で，各ページとも 左側 $1 / 4$ はヘッデイング用にあけてある. 活等の 大きさ, 特にその字体か読みやすく, 文章, 図のレ イアウトが非常にすぐれている，但し，特殊な活字 を使用しているので，印刷コストが普通より高くつ いている，又，無理につめこむことをせずスペース が随所にとってあるので，読みやすい.

（3）データの詳細を付録にゆずっているのは妥当であ る.

（4）大気拡散・水質・騒音・日照の予測シミュレーシ ヨンをマイコンによって行って扣り, 乙の程度の事 業ならてれで十分である。

欠点としては

（5）騒音防止対策（田中／1976）(p. 141), 騒音・振動 対策ハンドブック（発行所・年度なし）〔p.152]，な ど,引用文献の示し方が不正確で,これだけでは探 し出せない，論文であれば著者・発表年・雑誌名・ 巻号・ページが必要であり, 書籍であれば編著者・ 発表年・書名・発行所が必要である, 又, p.1490塩

*名古屋大学理学部教授 Yasuo SHIMAZU
用論文の引用に見るように，文献名が文中にある上， かつ萝通の記載方法に上っていないため, 見にくい あのがある。やはり章ごとに柅にま之めて小すの がよからう。

（6）実施計画が確定していないため, 設供諸元に明確 でない点があり，予测の前提が不満足である。同様 の事情から，工程計画が示されて抢らず，工事中の 影響評価が不十分になっている。

(7) 数式の記載は許容出来る範井であるが,やはりミ スプリントが発生している。

2 事業計画・計画地域の特性（第 2, 3 章）

（1）事業の必要性，特に忌避施設を作ら权ばならない 理由，イメージアップのためによ゙んな方策をとるか を述べているのは妥当である（p.10１1）。

（2）しかし低希釈二段活性污濁法之はどんなものか, 高度処理とは何かを説明する親切がほしい。p. 140 平面図の右ページは空白になっているのでここに 説明を記載するとよい。な打，平面図だけでは施設 のイメージがはっきりしない。ややは斎場・清掃工 場を含めた写真か, 透視図 (パース) が必要であろ う.

(3) p.13，16の地図は似たものの重複でかつ読みにく い. 立地上の特性を理解させるには, 次の点の強調 が必要である。即ち

（i ）乙の地区には，斎場・清掃工場・既設の衛生処 
理場, さらに木曽川町清掃センターが一ケ所に集 まっているてと。

(ii ) 排水先である野府川の流域構造

(iii）搬入車の搬入ルートとの関連で, 道路網の状況 p.16の図をp.13にもって行き,p.16には上記のて とを明示した方がよい。

3 環境への影響項自之関係地域の設定（第 4 章）

関係地域の設定にあたっで，機械的な方式をとらず， 項目别俘予備計算を行って設定しているのは妥当であ る. p. 53の設定図は理解を助けるのに適切であるが, 地図をそのまま使っているのでやや読みにくい.

4 環境の現況之影響予測及び評価（第 5 章）

(1) 環境項目別に現況から評価までを記載している点 は妥当であるが, 12項目にわたる記載を第 5 章一つ に入机て抢り，その為一つの章の分量が 182 ページ (本文の73\%) になっている. 従って, ランニング・ タイトルが182ページにわたって「環境の現況と影響 予測及び評価」だけになって打り，それぞれの項目 の記載個所が検索しにくい.むしろ, 水質・大気・ ・・の各項目をランニング・タイトルにすべきであ る.

(2) p. 112 114の大気活染パターンには，予測に用い た16方位の風向きがそのまま現れており，適切でな い.

（3）騒音レベルのの単位に $\mathrm{dB}, \mathrm{dB}(\mathrm{A})$ ，ホンが混ざっ ている。

(4) 悪臭では悪臭物質濃度を臭気濃度とよんでいるが, これは正確でない。三点比較式臭袋法を用いた感覚 的な指数を普通臭気濃度とよんでおり，てれによる 評価む必要である。又, 排出源はp.165にみるように 多数あり, ダクトで一個所に集中して放出するとし ているが，その位置㧍よび性能を記載してないので, 点源を仮定した拡散予測の結果か妥当かどうか判断 できない，現況（これは多数点源）の再現計算もな い.

\section{5 概要版の試作}

第 9 章に述べた趣旨に従って, 本事例に対し, B 4 版 4 ページ（B 3 版裏表印刷を折返りしたもの）の概 要版を作成した。特に注意したのは次の点である.

(1) 事業の概要・地域の概要の記載に全体の $20 \%$ をあ て、しかむ，乙れらのうち，環境への影響の観点か ら重要と思われるものを重視している。 いわゆる忌 避施設を作るにあたっての建設理由,イメージ改善 のための配虑点, この地区が斎場・清掃工場・衛生
処理場の一体となった特別な所であるてと、などで ある。

（2）供用後の影響の記載には50\%をあて，見開き 2 ペ 一ジに収まるよう配慮してある。そして，項目別に 文章の形にした例と, 表の形にした例との双方を示 した．同じスペースをとっても，文章形式の方か内 容豊富になっている，さらに，形式によって表現の ニュアンスに差の出るてとに注意してほしい. 文章 にすると，説得性か強くなる代わり，押しつけにな る恐机がある。よ゙ちらがよいかは一口にはいえない が, 項目数が少ない場合は文章形式，多い場合は表 形式がよいかもしれない.

（3）計画地域を示す図は，一般的特徵の項で述べたよ うに，分かり易いものに取替えた方がよい。

(4) 項目記載の順序は, 影響か重大と思われる順にな っており，必ずしも原評価書の記載順になっていな い。乙扎より，大要がつかみ易くなっている。概 要版の場合結果だけを示すだけになり, 何故そのよ うな結論になるかを示す余裕はないが, 論理の流れ は明確につかめなくてはならない，その目的には， 表形式がすぐれている，表を横に辿ればよいからで ある。

(5) よいととずくめのクリヤー宣言にならぬよう，あ りのままを示すととを考えている。一方, 事業者の 責任に係万事項を明確にし, 対策は具体的に示す.

(6) 工事中の影響は 4 ページ目に迴し，しかも重要な あのだけに止めてある。

(7) 乙の事例では，環境影響評価が制度化されていな い. そして, 作成後に評価書が公表されるだけで, 準備書修正の手続きがない，4ページ目後半の, 手 続きに関する記載は, てのてとを反映している。

(8) 原評価書では，騒音に扔けるホン・ $\mathrm{dB}$ など単位 に統一がないが，こてでは適宜揃えてある，悪臭の 項も変えてある。電波障害・日照阻害の予測に不十 分なところがあるが, 本事業ではあまり重要な項目 ではないので, 原評価書の記載を之のまま使用して いる。

(9) 日本語ワード・プロセッサを使用している，字の 大きさが二種類泿られているが, 手間・コストの ことを考えれば，乙の程度でも良いのではないか. な技, 多色刷の効果は試みなかった。 


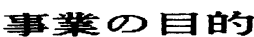

都市化が急速に進む中で，一宮市のし尿処理能力は限界 にきています。そこで，現在の処理場を改䇣するととも に，南側の隣接地への搪張をはかり，処理能力を三倍に することを考えております。これにより，市内のし尿と 净化䊰污泥のすべてを処理することができるようになり ます。

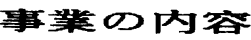

処理能力

$$
\begin{aligned}
& \text { 新設分 } 200 \mathrm{kl} / \text { 日 } \\
& \text { 改設分 } 100 \mathrm{kl} / \text { 日 計 } 300 \mathrm{kl} / \text { 日 }
\end{aligned}
$$
内訳注

$$
\begin{array}{ll}
\text { 生し尿 } & 70 \% \\
\text { 浄化槽污泥 } & 30 \%
\end{array}
$$

処理方式 低希积二段活性污泥法 発生污泥は焼却処理

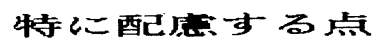

・手気を出さないようにする，排水を極力 少なくするため低希釈処理を行うなど， 公害防止につとめる。

・設倫を建屋の中に納め, 水槽は出来るだ け地中において，目立たぬようにする。 安全で安定した運用管理を行う。投入車 の管理に注意する。

以上により，衙生処理場のイメージ改善 につとめます。

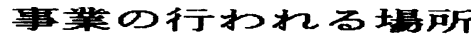

一宮市奥町字六丁山 市の西北端にあり，木甾川町との境てす。

—は新しく搪張する部分て，

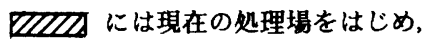
一宮市の音場・清掃工場（ごみ烧却場） ・木曾川町清掃センターがあります。 処理場からの排水は西に隣接する野府川 へ排出します。
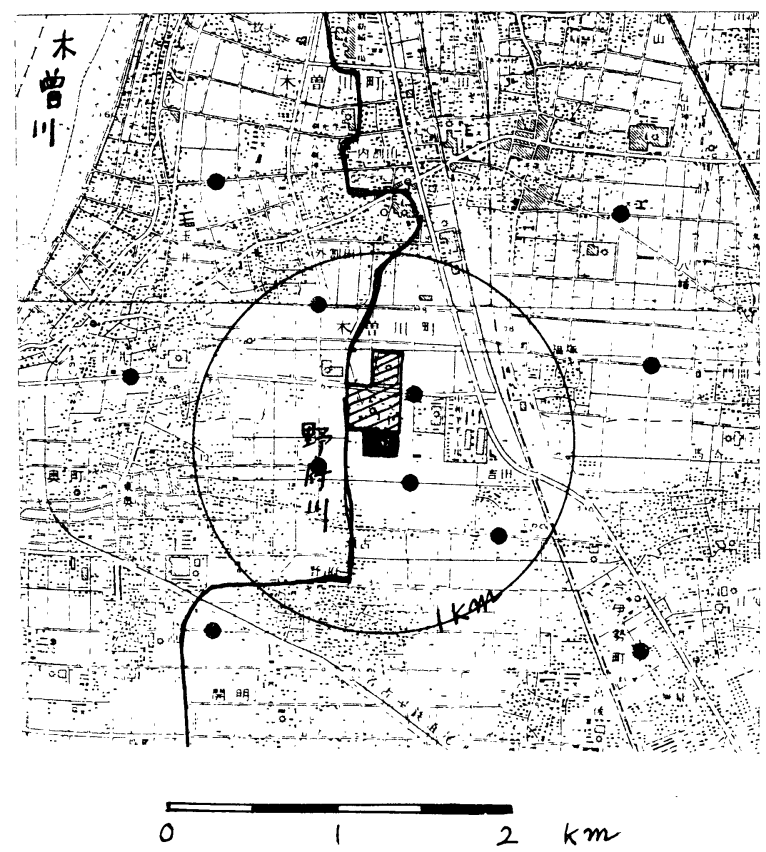

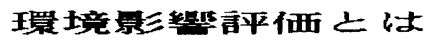

事業の実施が，人の健康や安全で快適な生活，さらに動植物を含む自然に与える 影響を，前もって予測し，適切な対策を考えます。そして，この結果を文書にま とめて公開し，地域の方々の御意見を事業の実施に反映させます。以上を合わせ て環境影響評価とよびます。 このパンフレットは，環境影響評価の結果のあらましを示したものてす。考えら

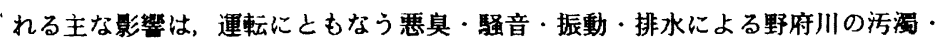
污泥焼却による大気污染・車両の出入りによる交通事故などです。これらの影嘰 を次のページに示しました。 


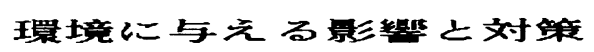

\section{慧臽}

・処理場のイメージを左右するのは，まず悪自てす。 一年を通して主に風下となる南東の数地境界で，主な剅 真物算の現況懐度は表の通りてす，これらの原因は現存 する処理場，清掃工場てす。

$\begin{array}{lcc} & \text { 現況 }(\mathrm{ppm}) & \text { 発生源 }(\mathrm{ppm}) \\ \text { アンモニア } & 0.02 & 1 \text { 以下 } \\ \text { 硫化水素 } & 0.002 & 0.02 \text { 以下 } \\ \text { メチル } & \text { 测定限界以下 } & 0.02 \text { 以下 } \\ \text { メルカプタン } & & \end{array}$

さらにここれらの悪真物澌の混ざったものを，人は臭 見として感ずるわけですが，真見の強さは真気瀿度とい う指数て表され，現況てこの大きさは15以下てす。

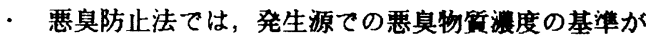
決められておりここれ上の表の通りてす。本事業ても この值を守ります。又, 政地境界ての臭気濼度を, 準工 業地域て苦情の出ない限界とされている15以下にするこ とを目標とします。

・発生した悪真物犋は，風にのってひろがります。気 象条件を考えて予測すると，贱地境界より外ては，上記 の目標値をこえることはなく，平常時に不快を感ずるこ とはありません。

・ しかし，運転ミスなどで悪臭が一時的にもれ，これ が不快感を与えることが考えられるのて，発生するガス はすべて一ケ所に集め，脱自装置を通してから排出しま す。又, 車の出人口にはエアカーテンをつけ, 内部の空 気を遮断します。

\section{騒音・手辰重力}

- 数地境界での騷音は，昼て50〜 55db（A），夜は44 〜49db（A）てすがこれは規制基隼を下回っています。 主な，騒音源は現在の処理場・清掃工場てす。

・消化槽ブロアー・キルン・競水機・コンフレッサー などは，機楖から1mのところて70〜90db（A）の㩆音を 発生しますが，これらは建物の中におくか，防音装軎を つけます。
野府川はさんて住宅もあるのて，処理堨からの趶 音を，数地境界て昼夜とも45db（A）以下におさえるこ とを目標にします。建物による遮音奻果も考えて、これ は十分達成てきます。

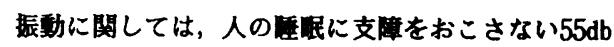
（A）以下にすることを目標にし，具音の堨合と同じよ うに，数地外てこれを连成することができます。

\section{水铂}

- 処理場からの排水は，野府川に排出します。野府川 は, 有磯物污渭が進んており,この地域の現状水算は表 の通りです。

\begin{tabular}{|c|c|c|}
\hline & 現況（ppm） & 放流水（ppm） \\
\hline BOD & $10 \sim 15$ & 10以下 \\
\hline COD & $20 \sim 30$ & 20以下 \\
\hline$T-N$ & $3.6 \sim 17.6$ & 10以下 \\
\hline$T-P$ & $0.85 \sim 1.96$ & 1以下 \\
\hline & $\begin{array}{c}\text { 色度 } \\
\text { 大晹菌釉 }\end{array}$ & $\begin{array}{l}\text { 20度以下 } \\
3000 \text { 佃/m1以下 }\end{array}$ \\
\hline
\end{tabular}

なお，現処理場からの放流水のBOD は25 ppmて，SSとと もに基準すれすれです。

・野符川の水篗を現状より悪化させないことを目標に， 放流水の水筫を表の值におさえるよう，処理します。こ れにより, 排水口のすぐ下流で, BODは1ppm減り，わずか ながら改善されます。

・ しかし，何分にも野府川自身の污湓が進んているの て，野府川の浄化には役立ちません。このためには，上 流を含めて流域全体の対策が必要てす。

\section{大気}

現処理場ては，発生する污范を乾爆した上，外部に 持ち出しています。新しい処理場ては，これを烧切処理 した上，1 日800kg の焼却灰を処分地に持ち出します。 
・このあたりでは, 現在1 時間値の1 日平均か

二䣲化硫黄 $\quad 0.017 \mathrm{ppm}$

二酸化窒素 $0.04 \mathrm{ppm}$

ばいじん $0.18 \mathrm{mg} / \mathrm{m}^{2}$

て，環境基準をみたしています。

・䗷却を行うことにより，排ガス量は㘿加しますか， 大気灌度について現状を悪化させないことを目標にしま す。

気象条件を考えて，排煙の拡散を計算すると，最大 着地瀿度の变化は1 \%以下です。

\section{文通隺全}

・衛生処理場て考えなくてはいけないのは，車両の出 入りです。稼侽がはじまると，1日の股入車は168 台て， 10〜12時及び15〜16時のビーク時には, 1時間32台に達す るものと推定されます。

- 現在搬入車は南の県道奥一江南線（平均て1 時間あ たり280台の交通量）を経て，野府川左岸道路（1 時間 あたり80台）から出入りしています。今後も主にこの経 路をとることになるでしょうか，この場合，ピーク時に， 県道では1 分5 台の交通量が6 台に, 左岸道路では1 分 1 台が2 台に增えます。

・投入車の泚滞は, 施設のイメージダゥンの原因です が，もとと交通量の少ない地区なので，上記の交通量 增加も，泚滞の原因にはなりません。

·なお, 車両の出口・入口をわけ, 経路については, 関係機関 (警察) と十分協竓し, 安全設传をつけます。

\section{查镜}

・この地区は，農地のひろがる田園地域であり，集落 から孤立しています。しかも，音場・基園・清掃工場が 一体となった地区です。現処理場の建物高は $10 \mathrm{~m}$ 以下で， 清掃工場の方か目立ちます。

・ 以上の現況にもとづいて，新しい処理場が䡒钼上違 和感をおこさないことを目標にします。

・このため, 緑地帯を設けて視覚上の配虑を行います。 新処理場の建物高もこれまで通り $10 \mathrm{~m}$ 以下てすし，新設 の場合に比べて違和感は大きくないと考えます。

\section{日照阻害}

日照阻害で特に問題になるのは，数地の北侧と西侧 ですが，北は韵場です。西侧に3 階アパート1 模，民家 1 戸か隣接していますか，処理場の建物高か $10 \mathrm{~m}$ の時， 冬至の日の8 9 時に, 上記の家が日陰になります。

・普通，日照阻害の対象になるのは，冬至日に日陰時 間が4 時間以上という場合ですが，建物棈造を更に湌討 して，日陰時間を最小にするよう配虑します。

\section{西波障䈍}

・この地区は，テレビ放送局から20〜30kmのところに あり，電波は南東方向から来ます。

建物の陰による障害は20〜30m の筑囲と予测され， 教地内に収まります。反対波による障害の筑囲は，もっ と小さいものと予测されます。

・しかしもしテレビ受信に影響が出た場合は，共同 アンテナ又は個別アンテナを設置します。

\section{㞣瑟物}

大気の項で述へたように，污范処理に伴って烧却灰 が発生します。

この烧却灰は業者が処分地へ持ち出しますが，その 際，若干水分をもたせ，又シートをかぶせて，大気への 飛散を防止します。

\section{士堆}

・ この地域の土㭛はカドミウム $0.18 \mathrm{mg} / \mathrm{kg}$, 砳素 1.8 $\mathrm{mg} / \mathrm{kg}$ を含みますが,これは一宮市内の平均濼度てす。 ・媇却に伴うばいじんによって，重金属や有害物斦か 二次的に土壌を污染する心配はありません。

\section{地盤沈下}

・地盤沈下がおこると，回復がむずかしいので，地下 水位の低下を含めて，障害をおこさないようにしなけれ ばなりません。

この地域は沖榬地の典型的な地局で，表居 $20 \mathrm{~m}$ は 軟弱ですが, $20 \mathrm{~m}$ より梁い所は玉石混じりの砂屏て す。ここまで基碳をおろせば，建物支持力は十分て，施 工に伴って周囲に地盤沈下をおこすこともありません。

又，新たに地下水の揚水を行わないのて，これによ る地盤沈下の進行や，地下水位の低下はおこりません。 


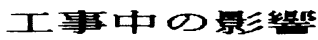

建設には約二年かかる予定てすが，その間に考えられる影㲫として，次のものがあります。

騷音

・ r特定建設作業に係る規制基準」を守り

ます。その内容は空気圧縮機て $75 \mathrm{~dB}$ (A)

以下などです。

・敖地境界てこの目標檤を達成できると予 测されますが,なお，低騷音型の機器を使用

し，必要に応じて防音シ一トを用います。

\section{振重力}

・騒音の場合と同じく、r特定建設作業に 係る規制基準」を守ります。その内容は，杭 打ち機て $75 \mathrm{~dB}$ (A) 以下などてす。

・数地境界でこの目標値を達成できます。 しかし，低振動型の機器を使用するなどの注 意をします。

\section{地譥沈下}

・ 工事に伴って地盤沈下や地下水位の低下 を生じないようにします。

・矢板打ち込みによる影響は，教地内に止 まります。

\section{発重要物}

・既設の処理場を塿すのて，廃材 60000 トンが発生します。これは業者が持ち出して 処分します。

・ その際，r廃萧物の処理及び清掃に関す る法律」を守り，周辺の方々の日常生活に着 しい影譬を与えないよう注意します。

\section{文通夷全}

-工事車両の出入りによる交通量の增加か， 周辺の一般交通や歩行者の安全に支障を来さ ないようにします。

・現在の交通量が少ないので，交通洪滞は おこらないものと予测します。

・大型車・特殊車両の運行には, 経路など について関係機関（整察など）と協境し，通 転者には交通法規を䔔守させます。

以上の環境影響評価の結果により，この事業は環境に大きな影䭗を及ぼすこ とはないものと判断します。今後,この結果を，事業の実施に生かすことに します。

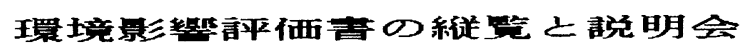

維卧場所 一宮市市民部清掃課（一宮市奥町字六丁山）

期間

地元説明会の場所・日時は町内会を通じて追ってお知らせします。

環境影響評価についての御意見・御哲問は

一容市市民部清掃課

$0586-45-4423$ - 


\begin{tabular}{|c|c|c|}
\hline & 現汾 & 罾士设军全回標 \\
\hline 䛶素 & 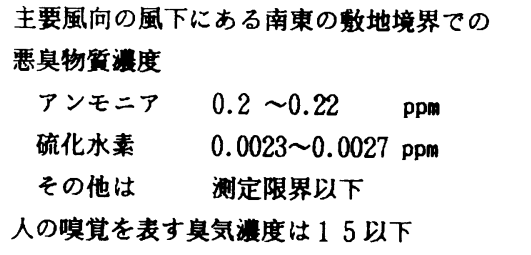 & 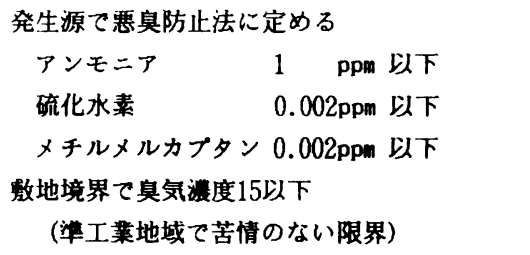 \\
\hline 㥍兽 & 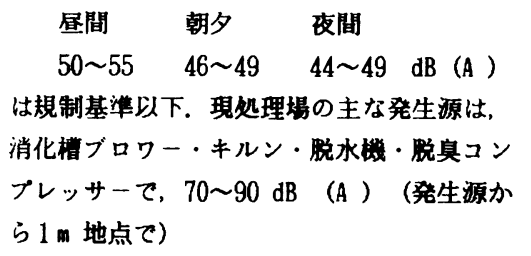 & 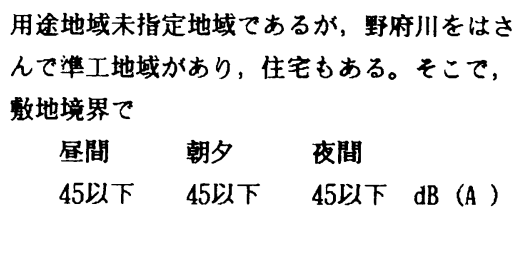 \\
\hline 振重力 & 昼間 $40 \mathrm{~dB}$ (A） 以下で, 規制基望を下廹る & $\begin{array}{l}\text { 人の睡眠等に与える振動の影䍶についての科 } \\
\text { 学的知見より，昼間 } 55 \mathrm{db} \text { (A） 以下, 夜間 } \\
55 \mathrm{db} \text { (A) 以下 }\end{array}$ \\
\hline 水很 & 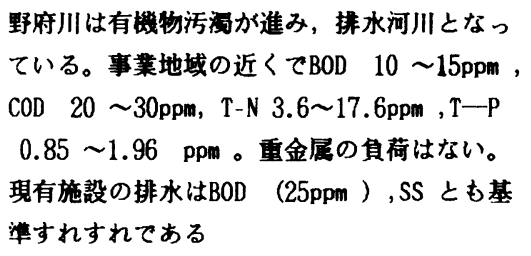 & 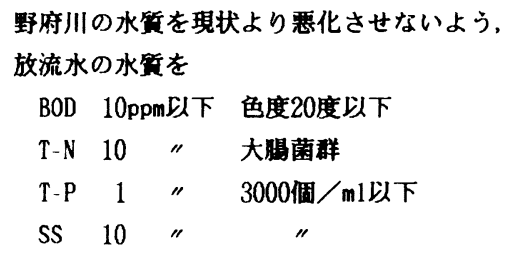 \\
\hline 大文 & \begin{tabular}{cll} 
今伊勢町て & & \\
& \multicolumn{1}{c}{$50 \%$ 值 } & \multicolumn{1}{c}{$98 \%$ 值 } \\
二酸化硫黄 & $0.005 \mathrm{ppm}$ & $0.017 \mathrm{ppm}$ \\
二酸化窒素 & 0.019 & 0.04 \\
ばいじん & 0.075 & 0.18 \\
現有施設南東の一宮市常時钼测所では懪境基 \\
隼をみたしている
\end{tabular} & 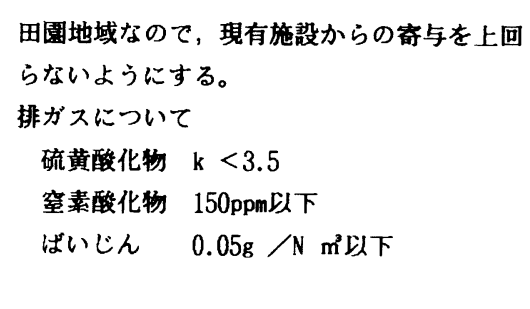 \\
\hline $\begin{array}{l}\text { 车通 } \\
\text { 承全 }\end{array}$ & $\begin{array}{l}\text { 計画地周辺の道路は } \\
\text { 東に県道名古屋一一宮線 } \\
\text { (平均 } 1000 \text { 台/時) } \\
\text { 南に県道奥一江南線（平均 } 280 \text { 台／時） } \\
\text { 西に野府川左岸道路（平均 } 80 \text { 台／時） } \\
\text { 現有施設への搬入は南から野府川左岸道路を } \\
\text { 経るのか普通 }\end{array}$ & $\begin{array}{l}\text { 交通量の增加が, 周辺地域の一般交通及び歩 } \\
\text { 行者への影㺦の及ばないよう考虑する }\end{array}$ \\
\hline 部観 & $\begin{array}{l}\text { 宸地の広かる田園地域にあり, 菓落からは孤 } \\
\text { 立している。計画地域は湆場・清掃工場が一 } \\
\text { 体となっている。現有施設の建物高は } 10 \mathrm{~m} \text { 以 } \\
\text { 下で, 高い清掃工場の方が目立つ }\end{array}$ & 違和感をおこさせない。 \\
\hline 日昰 & $\begin{array}{l}\text { 西側に3 階アパート1 棟，民家 } 1 \text { 戸。北侧は } \\
\text { 斎場 }\end{array}$ & 周辺の居住環境に著しい影㜪を与えない。 \\
\hline
\end{tabular}

污泥処理を乾娼から娔却に変えるため 1 日に $800 \mathrm{~kg} /$ 日の焼却灰が発生します。これは

業者が持ち出して処分地へ運びますか，报出の際，小量の水分を含ませ，又シ一トをかけ

て、飛散を防ぎます。 


\begin{tabular}{|c|c|c|}
\hline & 予测 & 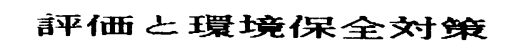 \\
\hline 传寔 & 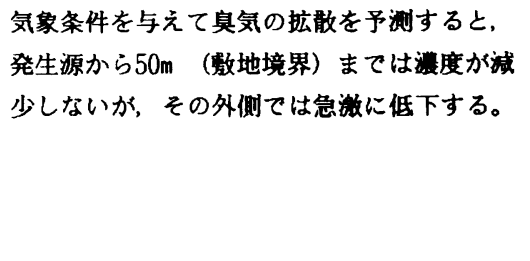 & $\begin{array}{l}\text { 発生源で目標值を達成すれば, 敕地外で通常 } \\
\text { 不快を感ずることはない。運転ミスなどによ } \\
\text { る一時的な臭気もれに対しても, ガスを一ヶ } \\
\text { 所に集中し脱真装置を通してから排出するこ } \\
\text { と, 出入り口にエアカーテンをつけること, } \\
\text { によって対処する。 }\end{array}$ \\
\hline 騒音 & $\begin{array}{l}\text { 清掃工場・韵場を含めた敷地内て } 45 \mathrm{~d} \mathrm{~B} \\
\text { (A) 以下。影響は北西方向の耚場に及ぶが, } \\
\text { その他の方向では, 建物の遮音効果によって } \\
\text { 外部に及ばない。 }\end{array}$ & $\begin{array}{l}\text { 発生源である消化槽ブロア一等の機栈は屋内 } \\
\text { に設置し，屋外設置のものについては，防音 } \\
\text { 装置により，目標值は十分達成てきる。 }\end{array}$ \\
\hline 振胆力 & 敖地内で, 目標値の $55 \mathrm{~d} \mathrm{~B}$ (A) 以下 & $\begin{array}{l}\text { 通風機やこれに連結するダクトの配䈯を考え } \\
\text { て, 目標值は十分達成できる。 }\end{array}$ \\
\hline 水铂 & $\begin{array}{l}\text { 放流直下の野府川水啠は } \\
\text { BOD } 15.2 \mathrm{ppm} \rightarrow 14.2 \mathrm{ppm} \\
\text { のように改善される。 }\end{array}$ & 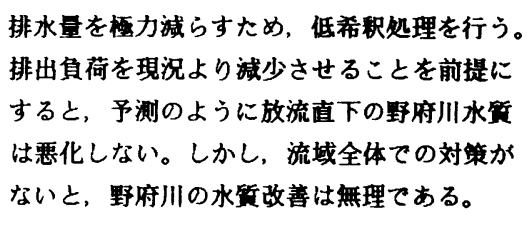 \\
\hline 大気 & 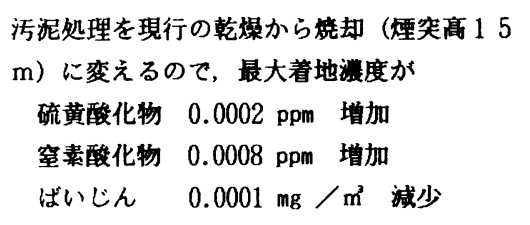 & $\begin{array}{l}\text { 排ガス量は増加するが，大気晸度の变化は微 } \\
\text { 少である。 }\end{array}$ \\
\hline $\begin{array}{l}\text { 胥通 } \\
\text { 㑒全 }\end{array}$ & $\begin{array}{l}\text { 一日の搬入車は } 168 \text { 台と推定され, ピ一ク時 } \\
\text { は10〜12時, } 15 \sim 16 \text { 時である。又, ビ一ク時 } \\
\text { には32台/時に達するものと予测される。南 } \\
\text { の県道では } 1 \text { 分あたり } 5 \text { 台が } 6 \text { 台へ, 野府川 } \\
\text { 左岸道路では } 1 \text { 分あたり } 1 \text { 台から } 2 \text { 台に增加 } \\
\text { する。 }\end{array}$ & 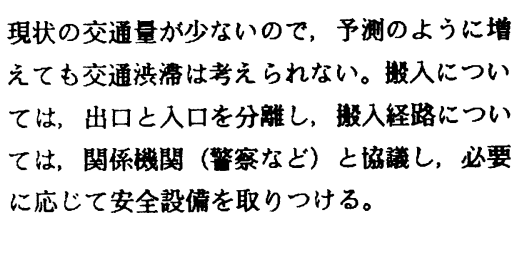 \\
\hline 豈钼 & $\begin{array}{l}\text { 現在既に施設があるのて，新設時に比へてて違 } \\
\text { 和感が小さい。 }\end{array}$ & 緑地帯を設けて，視覚上の配虑を行う。 \\
\hline 日昭 & $\begin{array}{l}\text { 建物高 } 10 \mathrm{~m} \text {, 煙突高 } 15 \mathrm{~m} \text { の場合, 冬至に } \\
\text { おいて西侧の数地境界外で, } 8 \text { 時から } 9 \text { 時ま } \\
\text { で日陰になる。 }\end{array}$ & $\begin{array}{l}\text { 建物構造を湌討し，日陰の筙囲を最小にする。 } \\
\text { 普通冬至に日陰 } 4 \text { 時間以上が補傊の対象。 }\end{array}$ \\
\hline
\end{tabular}

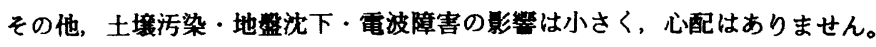


14. おわりに

本報告の作業が進んでいる段階で,

電通 （1982）環境影響評価に扔けるコミュニ ケーション技法の開発に関する調査研究報 告書 (昭和56年度環境庁依託), pp. 178 が公表された。その目的は本報告と同じである，その 目次は, 同報告書の結論をはっきり示しているので, 関係のあるところを再録しよう。

\section{I 環境影響評価準備書}

1 準備書の意義之課題

2 科学的推論江基づいて作成された文書の要件

- 論理をつかみやすい構成

・ 理解しやすく表現された情報

- 事実と意見との区別

- デー夕等の出所明示

3 準備書の内容構成

- 概要

- 事業者名

- 事業計画

事業の目的，事業の内容

- 調査

重要な情報を重視する

評価項目ごとに調查・予測・評価を記述 する

調査がどのように行われたかを明確にす る

- 予測

予測の手法及び予測の前提条件を明らか にする

予測結果を関係住民にわかりやすく表現 する

- 評価

- 資料編

専門的な検討に耐えうるに必要な情報を

網羅する

本文叙述と関連づける

書籍としての体裁を整える(別冊の場合 の章だて・目次の完備など)

4 わかりやすい文章

- 適切な用語

理解されやすい用語を使う（外国人名に は仮名を併用するなど）

あいまいな表現になりやすいことばに注
意する

・読みとりやすい用字

- 明瞭な文

なるべく短い文に分ける

明快な表現を心がける

・文章のまとまりをつかんだ表現 パラグラフを意識した記述 文章の展開を意識した記述 見出しの設定

- その他の注意事項

繰り返しの場合は参照ページを入れる 四表で説明してあってあ，文章だけ読ん でいけばわかるようにする チェック者の設定（推龍を念入りに）

5 表, グラフ, 地図, 図, イラスト, 写真, 数式 の示し方

6 論旨を把握させるための工夫, 読ませるための 内容上の工夫

・目次を整える

・リードをつける

・柱をつける

・表現か具体性を持つこ之

- 情報提供力を持つこと

・親しみをむたれること

・読み手の立場に立った作成責任者の設定

7 形態上の利便性の促進

- 見開き処理・分冊化・とじ

- その他の工夫

判の大きさ（B４を２段組み, あるいは A 4 )

文字書体, 大きさ, 字詰め, 改ページ,

段落, アクセント，紙面デザイン，紙の

色，表紙，みみ

- 印刷管理

II 公告

1 公告の方式

2 公告を補完して行うことが望ましい周知活動

・チラシ・パンフレット・ポスター・さまざま なパブリシティ・広告

III 縦覧

1 縌覽の方法

2 準備書縌覧の補完活動

・ 閲覧, 実費徵収のコピーサービス

- 貸し出し 
- 縦覧期間終了後の閲覧

IV 説明会

1 意義亡課題

2 企画

3 実施準備

4 進行

5 様々な形態

付 準備書の内容周知を補完するための概要を記裁 した文書

・用途とボリューム

- 概要の作成法
$\mathrm{V}$ 意見書

VI 公聴会

その他, 参考となる文献として

米国運輸省連邦道路局（1979）パブリック・ミー ティング及び公聴会の効果を高めるために（環境 庁訳）p p. 441

島津康男（1982）よい環境影響評価書とは， 自治体レベルの事業を主に, 環境情報科学, 11巻, $71-78$

がある。

\title{
第 2 回 環境科学 合同 研究 発表会
}

\author{
<日 時 > 昭和58年11月10日 (林，11日 (金) \\ <会 場 > 東京工業大学大学院総合理工学研究科大会議室 \\ （横浜市緑区長津田4259，東急田園都市線 すずかけ台駅下車 徒歩10分） \\ <主 催 > 環境科学合同研究発表会連絡協議会 \\ (北海道大学・筑波大学・神戸大学・広島大学・東京工業大学の関係研究科) \\ <問い合せ先 > 東京工業大学大学院総合理工学研究科（045-922-1111 内線2502）
}

11月10日(木)

\section{1. 環境化学}

・道路ぎわで採取した降下物の環境化学的特徴とそ の起源・都市下水污泥の化学組成とその起源・大阪 湾堆積物の磁化測定

\section{2. 教育・情報}

- 環境原論の教育事例報告・環境科学教育に打ける オンライン文献情報検索・情報環境論の動向

\section{3. 学内見学}

・キャンパス間テレビ講義室：超高電压超高真空高 分解能電子顕微鏡・MH D 発電実験装置：レーザー トンネル（長距離測定実験室）

4. シンポジゥム「環境科学におけるエネルギー問題」 ・ポリ酸イオンを光触媒とするバイオマスからの水 素発生・ポリフィリンによる光エネルギー変換・ク リンエネルギーとしての水素吸蔵物質の開発・長期 蓄熱媒体としての地盤の利用とその解析法・都市環 境とエネルギー・ソフトエネルギーを導入した地域 環境計画一十勝地域を事例として一・エネルギー開
発と環境保全とをめぐるコンフリクトの政治経済学 的分析・総合討論

\section{5. 想談会}

・長津田キャンパス内食堂

（会費 一般 3,000 学生 1,500円)

\section{1月11日(金)}

\section{6. 騒音}

- 大規模工業団地の開発に伴う周辺地域における環 境騒音の経年変化について・北海道内諸都市におけ る都市騒音の実態

\section{7. 緑地環境}

- 札棍市の緑地環境の動態・日本列島における照葉 樹林の組成分化と気候条件について・マングローブ 生育条件について

\section{8. 地域環境}

- 流域に打ける水系網の成長について・都市気温の 成因としての土地利用形態について・ネパール及び 日本の山地地域の活性化 